\title{
Projeto Genoma Humano: um retrato da construção do conhecimento científico sob a ótica da revista Ciência Hoje
}

\author{
The Human Genome Project: a portrait of scientific knowledge \\ construction by the Ciência Hoje magazine
}

\author{
Andréa Carla de Souza Góes ${ }^{1}$ • Bruno Vinicius Ximenes de Oliveira ${ }^{1}$
}

\begin{abstract}
Resumo: Em abril de 2003, o Projeto Genoma Humano (PGH), que havia sido iniciado em 1989, foi finalizado. Objetivamos, neste trabalho, relatar a evolução do conhecimento científico que culminou na proposição da sequência de nucleotídeos do genoma humano sob a ótica da revista Ciência Hoje $(\mathrm{CH})$, pioneira na popularização de ciência no Brasil. Analisamos a divulgação do PGH na revista $\mathrm{CH}$ de dezembro de 1984 a dezembro de 2010, intervalo que compreende: a motivação do sequenciamento do genoma humano, a fundação das instituições responsáveis pelo projeto e prosseguimento do PGH, a rivalidade com a empresa privada Celera Genomics, a publicação do primeiro rascunho, e consequências imediatas do projeto. Esperamos que a compreensão do pensamento reinante na época e dos estilos envolvidos nesse processo contribua para uma visão mais adequada da produção do conhecimento científico relacionado ao PGH e para a melhoria da educação científica de professores de biologia e de ciências.
\end{abstract}

Palavras-chave: Projeto Genoma Humano. Sequenciamento de DNA. Revista Ciência Hoje. Ensino de genética. Divulgação científica.

\begin{abstract}
The Human Genome Project (HGP), which began in 1989, was completed in April 2003. In this paper, we report the evolution of the scientific knowledge that culminated in the release of the human genome nucleotide sequence by Ciência Hoje $(\mathrm{CH})$ magazine, a pioneer in science popularization in Brazil. We analyzed the release of the HGP in CH through December 1984 to December 2010, a range that includes the planning of the sequencing, the foundation of institutions to undertake the project and continuation of the HGP, the rivalry with the private company Celera Genomics, the publication of the first draft and the immediate consequences of the project. We hope that the understanding of the spirit of that time and the styles involved in such process contribute to an adequate view of the scientific knowledge production related to HGP and improve the scientific education of biology and science teachers.
\end{abstract}

Keywords: Human Genome Project. DNA sequencing. Ciência Hoje magazine. Genetic teaching. Science popularization.

\footnotetext{
${ }^{1}$ Departamento de Ensino de Ciências e Biologia, Instituto de Biologia Roberto Alcantara Gomes, Universidade do Estado do Rio de Janeiro (UERJ), Rua São Francisco Xavier, 524, Maracanã, CEP 20550-900, Rio de Janeiro, RJ, Brasil. E-mail: acgoes@uerj.br
} 
Góes, A. C. S.; Oliveira, B. V. X.

\section{Introdução}

\section{O Projeto Genoma Humano}

O Projeto Genoma Humano (PGH) teve como objetivo o sequenciamento dos 3,1 bilhões de bases nitrogenadas do genoma humano. O genoma é o conjunto de DNA de um ser vivo, e o DNA é formado pela ligação sequencial de moléculas denominadas nucleotídeos. Estes são constituídos por três componentes, representados na Figura 1: a molécula de fosfato, a molécula de açúcar, denominada desoxirribose e a base nitrogenada. As bases nitrogenadas podem ser de quatro tipos: adenina (A), timina (T), citosina $(C)$ e guanina $(G)$. A ordem com que os nucleotídeos são dispostos no DNA é que faz com que uma molécula difira da outra. Podemos determinar esta diferença por meio do sequenciamento dos genomas. Como as moléculas de fosfato e açúcar são sempre as mesmas, a ordem da sequência é dada pelas bases nitrogenadas. Por exemplo, este pequeno fragmento de DNA representado na Figura 1 é constituído pela sequência AGCT.

Figura 1. O nucleotídeo é formado por uma molécula de fosfato, o açúcar desoxirribose e uma base nitrogenada, a qual pode ser do tipo adenina, guanina, citosina ou timina

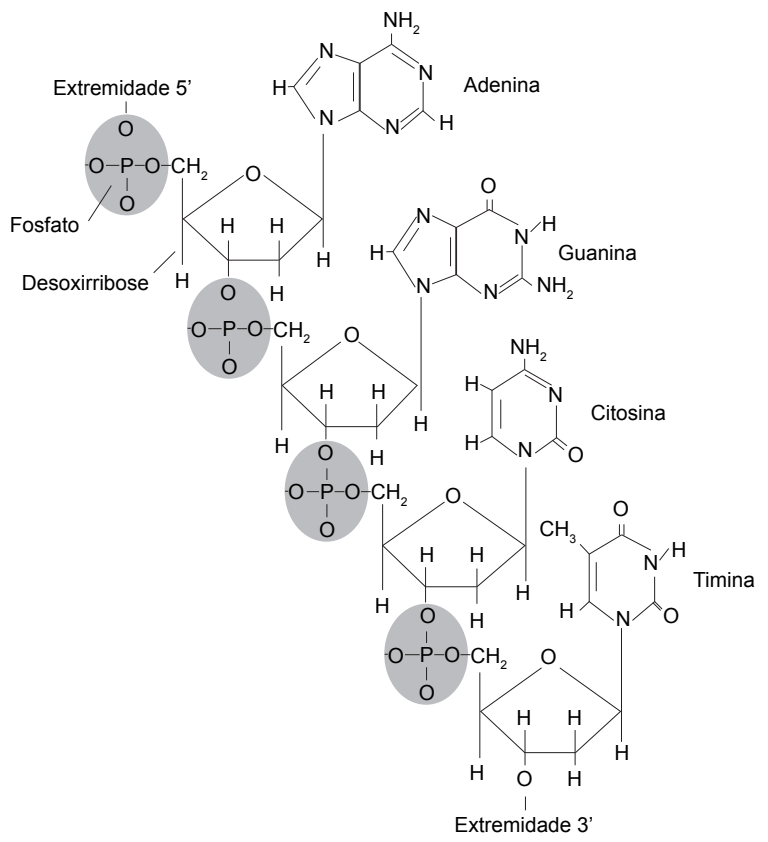

Fonte: Adaptado de: <http://www.enq.ufsc.br/labs/probio/disc_eng_bioq/trabalhos_grad2005_2/ constituintes/links/acidos.htm>. Acesso em: 10 jun. 2014. 
O grupo que se propôs a sequenciar o genoma humano consistiu em um consórcio público internacional, liderado pelo National Human Genome Research Institute (NHGRI), subordinado ao National Institute of Health (NIH) dos Estados Unidos. Reunindo equipes de pesquisa e laboratórios de vários países, seu objetivo central era o sequenciamento completo do genoma humano. Um dos projetos mais ousados no campo das ciências biomédicas, sua proposta foi lançada pelo Department of Energy (DOE) na década de 1980, motivada por um ímpeto de investimento em pesquisas genéticas, a impulsionar pesquisas relacionadas à Biologia Molecular. No caso do sequenciamento, o objetivo era construir uma base informacional que contribuísse para a medicina no campo das síndromes relacionadas a exposição à radiação.

Resultado de discussão ocorrida em vários encontros de Biologia Molecular, em 1989, o PGH foi oficialmente iniciado sob a direção de um dos responsáveis pela descrição da estrutura da molécula de DNA, James Watson, então diretor do NHGRI. Em 1992, Watson foi substituído por Francis Collins (LEITE, 2006). Dentro do país, o DOE era um importante colaborador. Fora do país, a fundação da Human Genome Organization (HuGO) garantiu a coordenação multinacional do projeto. A estimativa inicial de custo era de um dólar por base de DNA sequenciada (PENA, 2010), que projetava uma pesquisa onerosa; e o grande volume de informação a ser gerada sugeria, pelo menos, 15 anos para a sua conclusão.

A possibilidade de lucro com o patenteamento de regiões do genoma humano atraiu o interesse do cientista e empresário em biotecnologia John Craig Venter, que, em maio de 1998, anunciou a criação da empresa privada Celera Genomics. Uma joint-venture formada por meio do apoio capital da empresa de equipamentos e suprimentos Perkin Elmer, a Celera se comprometeu em sequenciar todo o genoma humano até 2001, contra o final então previsto pelo consórcio público para 2003 (PORCIONATTO, 2007). Com uma tecnologia inovadora, o whole-genome shotgun, empregada com sucesso no sequenciamento do genoma da Drosophila melanogaster (ADAMS et al., 2000), a Celera realizou o procedimento com o genoma humano em aproximadamente 13 meses (VENTER et al., 2001).

O investimento da Celera trazia preocupações ao consórcio internacional. Iniciava-se, assim, uma rivalidade que alavancou o PGH. Movidos pelo receio de um possível "loteamento" do genoma humano pela Celera, o PGH tomou por objetivo terminar seu trabalho antes da empresa privada. Segundo o geneticista Sérgio Pena, "Estima-se que o projeto público tenha usado seiscentos sequenciadores de DNA espalhados em laboratórios de vários países. Por outro lado, a Celera utilizou cerca de 300 sequenciadores, todos sob o mesmo teto" (PENA, 2010, p. 65).

A corrida entre os dois grupos terminou com a apresentação, em rede mundial, do rascunho do genoma, na cerimônia do ano 2000 na Casa Branca (Figura 2). "Os diretores dos dois grupos rivais, Francis Collins e J. Craig Venter, declararam uma vitória conjunta - e anunciaram uma trégua implícita - em suas corridas para decifrar o livro da vida" (PORCIONAT'TO, 2007, p. 54).

Porém, a publicação desse rascunho só ocorreu em fevereiro de 2001, dias 15 e 16, respectivamente pelas revistas Nature e Science (Figura 3). A conclusão oficial do projeto aconteceu em abril de 2003, junto às comemorações dos cinquenta anos de descrição da estrutura molecular do DNA. 
Góes, A. C. S.; Oliveira, B. V. X.

Figura 2. A divulgação do rascunho do genoma, no ano 2000, em cerimônia na Casa Branca

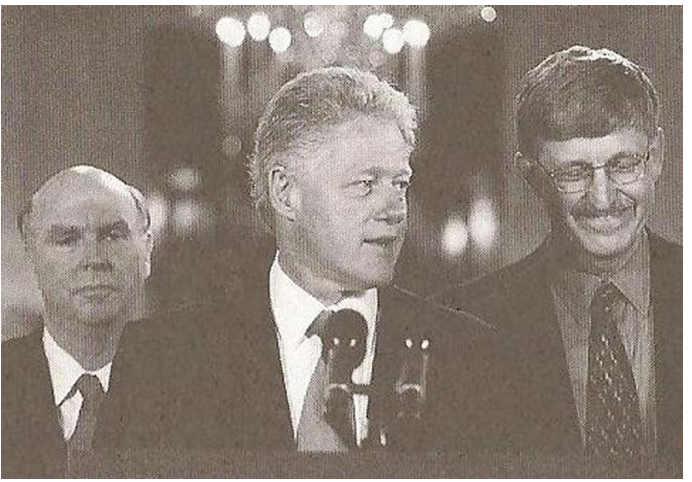

Legenda: da esquerda para a direita:

Craig Venter, o então presidente dos

Estados Unidos Bill Clinton e Francis Collins.

Fonte: <http://www.the-scientist.com/?articles.view/articleNo/12937/title/The-Human-Genome>. Acesso em: 18 jun. 2014.

Figura 3. Capas dos periódicos Nature e Science, respectivamente de 15 e de 16 de fevereiro de $2001^{2}$.
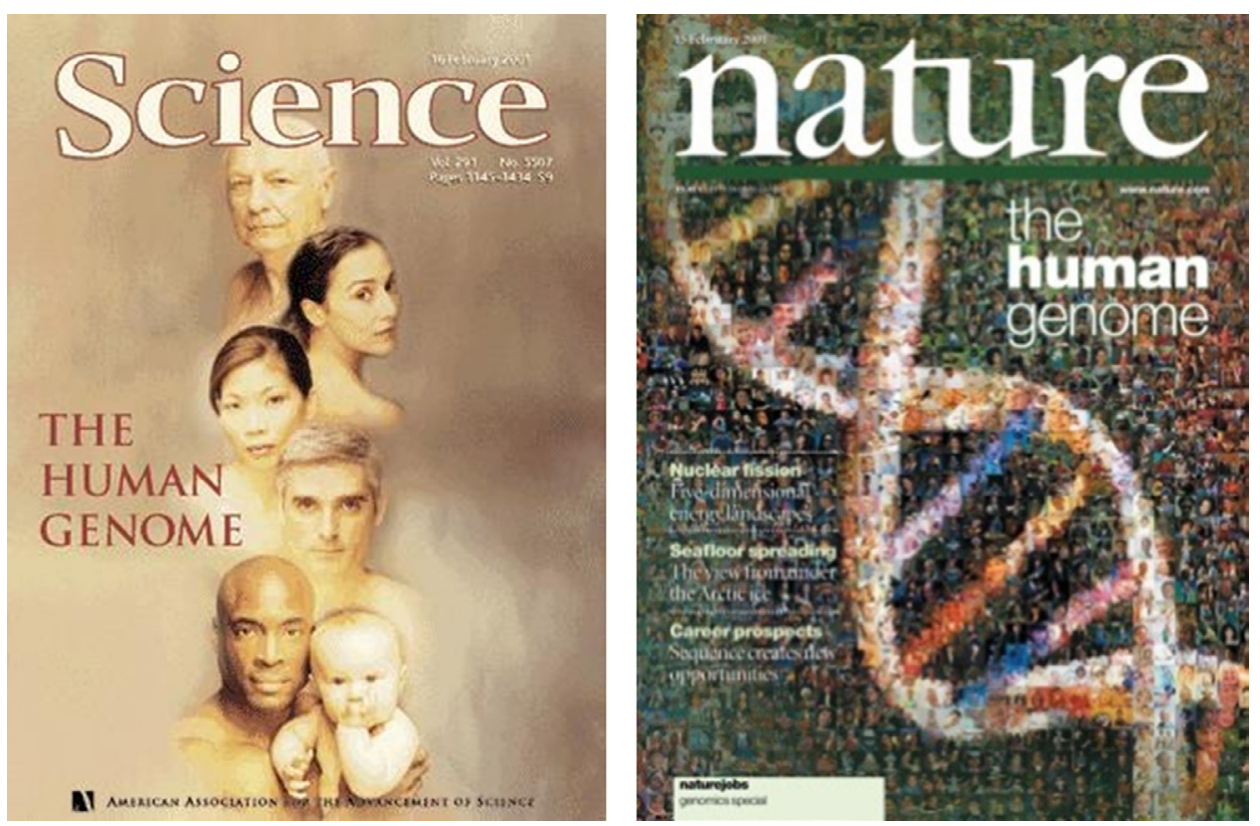

Fonte: Leite (2003).

${ }^{2}$ Volume 409, número 6.822 e volume 291, número 5.507, respectivamente. Nature apresentou 39 artigos sobre o genoma, enquanto Science apresentou 32 (LEITE, 2006), correspondendo a uma considerável proporção de seus conteúdos ao tema. 
O produto final do projeto consistiu no sequenciamento de um genoma-referência composto por genomas de diferentes povos. Eram amostras de doadores anônimos, oriundos de diferentes grupos étnicos. Em 2007, foi descrita a primeira sequência genômica completa diploide de um único indivíduo. Essa foi conhecida como HuRef, e o genoma, no caso, era o de Craig Venter (PENA, 2010).

Por sua vez, a conclusão do Projeto Genoma não atendeu as expectativas propagadas por Francis Collins: benefícios imediatos que levariam à cura de diversas doenças congênitas e grande avanço às pesquisas biomédicas (LEITE, 2006). Sem dúvida, houve um imenso avanço em relação ao conhecimento do genoma humano. Mas, se no início do milênio a mídia esperava noticiar avanços médicos com grande euforia, no fim dessa mesma década, humildes reportagens e entrevistas apresentavam a dificuldade de um leigo identificar ou entender algum benefício imediato resultante do sequenciamento do genoma humano (PRONIN, 2010).

As perspectivas pós-genômicas encontram-se no surgimento de outras áreas de pesquisa, outros "omas", onde o genoma se apresentava apenas como uma informação inicial, o pioneiro. No entanto, o avanço que o pioneiro estudo da genômica trouxe teve efeito avassalador na "Biologia Molecular do século XXI", como um ponto de partida básico, uma referência, que guia estudos e investigações a um sem-número de descobertas a cada dia.

\section{Divulgação científica}

Como um portal de comunicação entre a academia e o público em geral, a divulgação científica possui papel importante no processo de construção do conhecimento científico pela população. Traz à discussão notícias e conhecimentos do cotidiano da pesquisa científica em linguagem acessível ao cidadão comum. Auxilia em sua formação, assim como no aumento da qualificação geral científico-tecnológica da sociedade (MOREIRA, 2006). Logo, possui um papel essencial na educação científica do indivíduo.

As novidades tecnológicas e descobertas científicas, cada vez mais, se aproximam do cotidiano da população em geral, e suas consequências são de importância direta para o cidadão e a sociedade. Assim como a alfabetização ortográfica e gramatical se tornou indispensável para o exercício pleno da cidadania no século XX, em tempos de vida artificial, recriação do Big-Bang, desastres ambientais em escala local e consequência global, a alfabetização científica e tecnológica é de suma importância para o cidadão do terceiro milênio.

Segundo Scheid, Ferrari e Delizoicov (2005), a sociedade contemporânea clama por uma educação científica que atenda às exigências decorrentes do estado atual do conhecimento científico e suas aplicações, especialmente na área da genética. "Ao contrário do que frequentemente ocorre em economia e política, pesquisas científicas raramente rendem uma manchete de jornal. Quando isso ocorre, é sinal evidente de que as coisas no mundo já não são as mesmas de antes" (CAPOZOLI, 2001).

\section{A revista Ciência Hoje}

Pioneira em divulgação científica no país, a revista Ciência Hoje $(\mathrm{CH})$ pode ser considerada um meio de comunicação direta do público leigo com o ambiente acadêmico e de pesquisa. De circulação nacional, a revista publicada pelo Instituto Ciência Hoje (ICH), sob a 
chancela da Sociedade Brasileira para o Progresso da Ciência (SBPC), possui grande parte de seus artigos escritos por importantes pesquisadores das principais universidades e centros de pesquisa do país, assim como jornalistas com experiência em divulgação de ciência. Essa característica confere confiabilidade à publicação, tanto pela comunidade científica, quanto pelos professores da Educação Básica.

Ciência Hoje nasceu de uma ideia proposta por Roberto Lent em 1978, porém, sua primeira edição data de 1982, após a estruturação da revista, por meio de financiamento do Conselho Nacional de Desenvolvimento Científico e Tecnológico (CNPq), da Financiadora de Estudos e Projetos (Finep) e da própria SBPC. A revista teve como editores fundadores: Roberto Lent, Alberto Passos Guimarães Filho, Darcy Fontoura de Almeida e Ennio Candotti, com um conselho editorial composto com grandes nomes de vários estados (ALVETTI, 1999; GUIMARÃES FILHO, 1992).

Desde lá, a "família Ciência Hoje” cresceu, ganhando o Jornal da Ciência Hoje, o encarte infantil (futura revista) Ciência Hoje para Crianças, e o suplemento Technologia, além de vários números especiais, como Amazônia, Nordeste, Eco - Brasil etc. (ALVETTI, 1999). A fundação do $\mathrm{ICH}$ oficializou os objetivos da $\mathrm{CH}$ para além da revista, que, após a popularização da internet, se integrou a uma plataforma virtual ${ }^{3}$, com colunistas fixos e grande diversidade temática, tanto para crianças, como para professores e pessoas leigas.

Desde 1982, são mais de trinta anos de publicações quase ininterruptas, onde, por diversas vezes, a revista sofreu mudanças estruturais e de layout, assim como o perfil de redação de suas matérias. A regularidade de sua publicação alterou-se, de bimestral para mensal, de acordo com a situação econômica da SBPC e do país. Porém, na última década, não somente a publicação se regularizou, como adquiriu grande qualidade. Atualmente, a revista publica 11 números anualmente, já que a edição de janeiro é publicada conjuntamente com a de fevereiro.

\section{Formação de professores}

No que tange ao professor de ciências, os cursos de formação continuada ainda são poucos perante a série de novidades e termos científicos que ganham nosso cotidiano em produtos e tecnologia e na mídia, essenciais em seu vocabulário. Nanotecnologia, antimatéria e engenharia genética estão presentes em nosso cotidiano há décadas, desde exames médicos ao alimento que ingerimos ou roupa que vestimos. Para os docentes, a compreensão dessas novidades deve ser contínua, assim como os pesquisadores e cientistas o fazem ao acompanharem periódicos científicos.

Diferentemente da população leiga, que não domina conceitos técnico-científicos, espera-se que o professor de ciências detenha esse saber, uma vez que compete a ele orientar a construção do conhecimento científico dos alunos. Logo, matérias de divulgação importantes, assim como os artigos dos cientistas, se configuram essenciais para a sua atualização. Quando se pensa no contexto escolar, a participação da divulgação científica ganha uma nova dimensão; e compete, ao professor, a erudição na linguagem da ciência, possibilitando cumprir seu papel

${ }^{3}$ Disponível em: <http://cienciahoje.uol.com.br>. Acesso em: 18 jun. 2014. 
social sem trazer prejuízos a seus alunos e à sociedade. Em tese, sua leitura deve ser isenta de equívocos, possibilitando trazer, à sala de aula, assuntos atuais em ciência, em uma discussão construtiva e relevante. O professor deve ser capaz de identificar fontes idôneas e realizar uma leitura confiável.

De acordo com Pinheiro, Silveira e Bazzo (2007), a importância de discutir com os alunos os avanços da ciência e tecnologia, suas causas, consequências, os interesses econômicos e políticos, de forma contextualizada, está no fato de que devemos conceber a ciência como fruto da criação humana. Leite (2004) sugere que o professor pode atuar como mediador entre os historiadores da ciência e os estudantes ao utilizar a História da Ciência como estratégia para problematizar concepções de ciência e conteúdos de ciências. Segundo Fleck (1986 apud SCHEID; FERRARI; DELIZOICOV, 2005, p. 224),

[...] a História da Ciência, inserida na educação científica, poderá oportunizar um caminho de orientação aos alunos na apropriação de uma concepção de ciência como atividade humana, construída na interação entre o sujeito cognoscente, o objeto a conhecer e o 'estado do conhecimento'.

Assim, como forma de lançar luz a um dos episódios mais importantes da história recente da ciência, o presente trabalho analisa a evolução do conhecimento científico que culminou na proposição da sequência de DNA do genoma humano, e sua aceitação pela comunidade científica sob a ótica da revista de divulgação científica Ciência Hoje. Esperamos que este "retrato" do Projeto Genoma Humano contribua para o desenvolvimento de uma visão mais adequada sobre a construção do conhecimento científico relacionado ao tema e para a melhoria da educação científica, especialmente na formação de professores de ciências biológicas.

\section{Metodologia}

Visando acompanhar o relato do PGH por meio da revista Ciência Hoje, foram investigados todos os seus números, em um intervalo que compreende de dezembro de 1984 a dezembro de 2010. Este período compreende desde a ideia original do projeto, sua concepção e desenvolvimento, até a sua conclusão. Foram selecionados 18 artigos cuja temática principal era o PGH, ou que divulgassem algum estudo ou discussão relevante ao tema, citando a importância do projeto (Quadro 1). A partir desses artigos, traçou-se uma evolução histórica do projeto, sob a perspectiva da revista, possibilitando caracterizar transformações conceituais e o impacto dos resultados do PGH na comunidade científica. 
Góes, A. C. S.; Oliveira, B. V. X.

Quadro 1. Artigos da revista Ciência Hoje selecionados durante o período de dezembro de 1984 a dezembro de 2010

\begin{tabular}{|c|c|c|c|c|}
\hline Identificação & Autores & Título & Seção & Instituição \\
\hline $\begin{array}{l}\text { v. } 5, \text { n. } 29 \\
\text { (mar/1987) }\end{array}$ & Galler, Ricardo & $\begin{array}{l}\text { Decifrando os genes } \\
\text { humanos }\end{array}$ & $\begin{array}{l}\text { Um Mundo de } \\
\text { Ciência }\end{array}$ & Fiocruz \\
\hline $\begin{array}{l}\text { v. } 15, \text { n. } 88 \\
\text { (mar/1993) }\end{array}$ & $\begin{array}{l}\text { Vieira, Cassio; Massarani, } \\
\text { Luisa; Muniz, Marise }\end{array}$ & A megaciência dos genes & É Bom Saber & Ciência Hoje \\
\hline $\begin{array}{l}\text { v. } 17, \text { n. } 99 \\
\text { (abr/1994) }\end{array}$ & Ciência Hoje e Convidados & $\begin{array}{l}\text { Como enfrentar os } \\
\text { problemas éticos do Projeto } \\
\text { Genoma Humano? }\end{array}$ & Debate & $\begin{array}{l}\text { Ciência Hoje, } \\
\text { Diversas }\end{array}$ \\
\hline $\begin{array}{l}\text { v. } 17, \text { n. } 99 \\
\text { (abr/1994) }\end{array}$ & Ciência Hoje e Convidados & O primeiro mapa do genoma & É Bom Saber & $\begin{array}{l}\text { Ciência Hoje, } \\
\text { Diversas }\end{array}$ \\
\hline $\begin{array}{l}\text { v. } 18, \text { n. } 101 \\
\text { (jul/1994) }\end{array}$ & Massarani, Luisa & $\begin{array}{l}\text { Combate a doenças } \\
\text { tropicais }\end{array}$ & Ciência em Dia & Ciência Hoje \\
\hline $\begin{array}{l}\text { v. } 24, \text { n. } 144 \\
\text { (nov/1998) }\end{array}$ & Garcia, Eloi & $\begin{array}{l}\text { O passo seguinte do } \\
\text { genoma }\end{array}$ & Opinião & Fiocruz \\
\hline $\begin{array}{l}\text { v. } 27, \text { n. } 158 \\
(\mathrm{mar} / 2000)\end{array}$ & Rumjanek, Franklin & O 22 já foi, só faltam 22 & $\begin{array}{l}\text { Mundo de } \\
\text { Ciência }\end{array}$ & UFRJ \\
\hline $\begin{array}{l}\text { v. } 27, \text { n. } 162 \\
\text { (jul/2000) }\end{array}$ & Belizário, José & $\begin{array}{l}\text { Proteoma: o desafio } \\
\text { tecnológico do século } 21\end{array}$ & Opinião & USP \\
\hline $\begin{array}{l}\text { v. } 28, \text { n. } 163 \\
\text { (ago/2000) }\end{array}$ & Zatz, Mayana & $\begin{array}{l}\text { A importância dos estudos } \\
\text { sobre o cromossomo } 21\end{array}$ & $\begin{array}{l}\text { Mundo de } \\
\text { Ciência }\end{array}$ & USP \\
\hline $\begin{array}{l}\text { v. } 28, \text { n. } 166 \\
\text { (nov/2000) }\end{array}$ & Costa, Vera & $\begin{array}{l}\text { Genoma decifrado, trabalho } \\
\text { dobrado }\end{array}$ & $\begin{array}{l}\text { Matéria de } \\
\text { Capa }\end{array}$ & Ciência Hoje \\
\hline $\begin{array}{l}\text { v. } 28, \text { n. } 166 \\
\text { (nov/2000) }\end{array}$ & Costa, Vera e Convidados & As promessas e os riscos & $\begin{array}{l}\text { Matéria de } \\
\text { Capa }\end{array}$ & $\begin{array}{l}\text { Ciência Hoje, } \\
\text { Diversas }\end{array}$ \\
\hline $\begin{array}{l}\text { v. } 29, \text { n. } 173 \text {, } \\
\text { (jul/2001) }\end{array}$ & Gilbert, Walter & Rumo ao proteoma & Entrevista & $\begin{array}{l}\text { Harvard } \\
\text { University }\end{array}$ \\
\hline $\begin{array}{l}\text { v. } 32, \text { n. } 192 \\
(a b r / 2003)\end{array}$ & Pimenta, Adriano & Os desafios do Proteoma & $\begin{array}{l}\text { Biologia } \\
\text { Molecular }\end{array}$ & UFMG \\
\hline $\begin{array}{l}\text { v. } 34, \text { n. } 202 \\
(\mathrm{mar} / 2004)\end{array}$ & Goffeau, André & As modas da ciência & Entrevista & $\begin{array}{l}\text { Université } \\
\text { Catholique de } \\
\text { Louvain }\end{array}$ \\
\hline $\begin{array}{l}\text { v. } 35, \text { n. } 208 \\
(\text { set/2004) }\end{array}$ & Sulston, John & Ética e Genética & Entrevista & $\begin{array}{l}\text { University of } \\
\text { Cambridge }\end{array}$ \\
\hline $\begin{array}{l}\text { v. } 35, \text { n. } 209 \\
\text { (out/2004) }\end{array}$ & $\begin{array}{l}\text { Prosdocimi, Francisco; } \\
\text { Santos, Fabrício }\end{array}$ & $\begin{array}{l}\text { Sobre bioinformática, } \\
\text { genoma e ciência }\end{array}$ & Opinião & UFMG \\
\hline $\begin{array}{l}\text { v. } 36, \text { n. } 215 \\
\text { (mai/2005) }\end{array}$ & Souza, Sandro & O ponto $X$ do sexo & $\begin{array}{l}\text { Mundo de } \\
\text { Ciência }\end{array}$ & Instituto Ludwig \\
\hline $\begin{array}{l}\text { v. } 38, \text { n. } 228 \\
\text { (jul/2006) }\end{array}$ & $\begin{array}{l}\text { Amaral, Paulo; Nakaya, } \\
\text { Helder }\end{array}$ & $\begin{array}{l}\text { DNA Não-Codificador: o lixo } \\
\text { que vale ouro }\end{array}$ & Biologia & USP \\
\hline
\end{tabular}

Fonte: Elaborado pelos autores. 


\section{Resultados e discussão}

\section{O nascimento do Projeto Genoma Humano}

Em março de 1987, a CH publicou o primeiro artigo sobre o futuro Projeto Genoma Humano. Na seção Um Mundo de Ciência, o pesquisador da Fiocruz Ricardo Galler publicou o artigo "Decifrando os genes humanos" (v. 5, n. 29), onde apresentou tópicos discutidos em um importante encontro de Biologia Molecular ocorrido em Nova Iorque, no qual o sequenciamento do genoma humano era o principal tema. Em fins da década de 1980, o alto custo em potencial do empreendimento trazia certa hesitação quanto à importância do projeto, considerando-se que não eram claras as aplicações práticas da informação que ele traria. A ameaça do desenvolvimento do projeto por iniciativa japonesa pressionava os americanos a tomarem a iniciativa e garantir o pioneirismo neste empreendimento, levando a discussão da criação de um instituto próprio para pesquisas do genoma humano e perspectivas para a tecnologia de sequenciamento. Todos esses pontos são relatados por Galler (1987), que destaca a importância do DOE nesse episódio, como seu apoio à aquisição de informações genéticas, além de sua contribuição a um importante e oneroso banco de dados de Biologia Molecular, o Genbank. A matéria traz o fato envolvido pela euforia inicial que essa proposta trazia, o nascimento das hipérboles que viriam a caracterizar o merchandising genômico nas próximas décadas, como a "chave-mestra para os segredos da hereditariedade". Porém, um longo hiato se sucede entre esse artigo e o próximo a discursar sobre o Projeto Genoma.

Já em 1993, o artigo "A megaciência dos genes" (v. 15, n. 88) dedicou-se em caracterizar o que era o PGH. Com uma expectativa exacerbada do potencial do sequenciamento do genoma humano, a euforia dos autores nesse artigo ficava clara em expressões como "o mais ambicioso programa de pesquisa biológica de todos os tempos", "mega aventura científica" e “o código químico necessário para moldar a vida." Mostra-se presente, também, a concepção, que permearia durante grande parte da década, de que o genoma humano era composto por cerca de 100 mil genes. Com boxes explicativos e denso texto em linguagem acessível, este artigo apresenta, sumariamente, uma perspectiva global do projeto, possibilitando uma visão mais crítica aos conflitos éticos e problemas no andamento do Projeto Genoma. Nesse contexto, o PGH já tinha uma história em andamento, um corpo de trabalho formado e metodologia elaborada, e o mundo começava a conhecer melhor o que viria a ser o genoma humano e o desafio de mapeá-lo.

$\mathrm{O}$ ano seguinte foi marcado por artigos peculiares. Em uma mesma revista, abril de 1994 (v. 17, n. 99), foram publicadas discussões éticas acerca do PGH, o qual se tornara mais popular na mídia, incluindo a $\mathrm{CH}$, e uma reportagem sobre a publicação do primeiro mapa do genoma. O primeiro, intitulado "Como enfrentar os problemas éticos do Projeto Genoma Humano?" (1994) foi um debate promovido pela revista, com opiniões de pesquisadores brasileiros acerca de questões éticas relativas ao PGH. É o primeiro artigo a se dedicar totalmente a um enfoque bioético. Porém, em alguns discursos fica clara uma perspectiva equivocada e visão reducionista sobre a contribuição da informação completa do genoma humano à ciência biomédica e à sociedade. Um dos convidados, em um discurso perigosamente simplório, deixa entender que o genoma abriga todas as informações da constituição de um indivíduo, inclusive seu comportamento. Para ele, por intermédio de um mapa genético, poderiam se traçar todos 
os potenciais de um indivíduo. O pesquisador defendia uma fantasiosa realidade futura, em que a utilização desta informação se faria necessária a decisões políticas e jurídicas, de acordo com a natureza do indivíduo. Porém, apesar deste e outros deslizes ingênuos, como a concepção de uma iminente terapia gênica eficaz, a surgir nos próximos anos (até hoje ainda inconsistente), há uma discussão coerente relacionada à preocupação com a restrição dos benefícios dos resultados do PGH a apenas parte da população. Quebrando uma perspectiva de ciência neutra, discute-se que a sociedade precisa se preocupar com os problemas sociais, que, em países como o nosso, causam mais mortes que doenças genéticas.

O outro artigo dessa edição, “O primeiro mapa do genoma” (1994), divulga a conclusão de um mapa genômico, publicado na Nature por um grupo de estudos francês, o Centro de Estudos do Polimorfismo Humano, liderado por Daniel Cohen. Este mapa ainda apontava a perspectiva de 100 mil genes para o genoma humano. Pesquisadores convidados da CH comentam e traçam perspectivas triviais aos resultados do projeto, como o estudo de doenças, questões éticas e legais, e possíveis tratamentos futuros, como a terapia gênica.

Nesse mesmo ano, a pesquisa de Cohen e a citação do PGH foram tópicos presentes em outro artigo da CH. No artigo "Combate a doenças tropicais" (v. 18, n. 101), é relatada a criação do Projeto Genoma dos Parasitos (PGP), e sugere-se uma contribuição de até 5\% da verba do PGH para esse tipo de pesquisa, com perspectivas de ser um conhecimento com potencial a ajudar no combate a doenças que assolam os países de terceiro mundo. No box denominado "Cooperar não é competir', uma discussão com dois pesquisadores que participaram da elaboração das linhas gerais do PGP, critica a necessidade de abrangência do PGH aos países de terceiro mundo, apresentando a aplicação à saúde e o benefício do paciente como principal objetivo do sequenciamento.

\section{O desenvolvimento do Projeto Genoma Humano e o nascimento da proteômica}

Em 1998, por sua vez, a CH começa a demonstrar maior maturidade sobre o PGH. Nota-se uma perspectiva mais realista e menos eufórica acerca do sequenciamento. Outros termos também emergem nesse contexto. Eloi Garcia (1998), no artigo intitulado "O passo seguinte ao genoma" (v. 24, n. 144), discute uma nova questão, a "proteína genômica", ou proteoma. Esta consistia numa nova investigação a se investirem esforços, a qual seria mais informativa que a genômica. Na proteômica, estuda-se um mapa análogo de proteínas dos tipos celulares e suas interações. Isso reflete a conscientização dos geneticistas e bioquímicos quanto aos limites dos resultados do PGH, que, por sua vez, revelou a necessidade da formulação de novas perguntas quanto ao objetivo de entender o completo funcionamento do organismo e suas células. Porém ainda há vestígios da empolgação do início da década, detectados em expressões como "desvendar os segredos da vida". É interessante destacar que o conceito clássico "um gene, uma proteína" ainda se fazia presente no discurso de Garcia. O sequenciamento já apresentava perspectivas mais claras, porém as consequências mais impactantes ainda estavam por vir.

$\mathrm{O}$ ano 2000 se destaca pelo acirramento da rivalidade entre os pesquisadores do PGH e a Celera Genomics, e pela iminência da publicação do primeiro rascunho do genoma. O projeto foi citado em muitos artigos desse ano, que, por sua vez, também foi caracterizado pela divulgação de projetos genomas de outros organismos. Dentre as citações publicadas na $\mathrm{CH}$, pode-se 
destacar a conclusão do mapa genético da bactéria agrícola Xyllela fastidiosa, pesquisa realizada por equipe brasileira (v. 27, n. 159), e o da Drosophila melanogaster (v. 27, n. 161), realizado pela equipe da Celera. A preocupação com a cobertura do PGH foi grande, em cinco artigos, que se dedicaram inteiramente a discutir os principais avanços do projeto, no decorrer desse ano.

O primeiro, “O 22 já foi, só faltam 22” (v. 27, n. 158), de autoria de Franklin Rumjanek (2000), constava na edição de março. A partir da publicação do sequenciamento completo do cromossomo 22 no periódico Nature, em um aprazível texto, Rumjanek (2000) traça um panorama onde já se pode observar a influência dos resultados preliminares no rascunho do genoma. Ele destacou a previsão errônea de 100 mil genes para a espécie humana, a qual já havia sido rebaixada para 61 mil. Também informou que as perspectivas de conclusão do projeto já se formavam, se fixando para o ano comemorativo de 2003 (50 anos da elucidação da dupla hélice do DNA).

Em julho, a temática do proteoma é retomada por meio do texto de José Belizário (2000), então professor e pesquisador da USP. Em "Proteoma: o desafio tecnológico do século 21 ” (v. 27, n. 162), o autor aponta que, no século que passou, conhecer a estrutura e funcionamento do genoma e caminhar para um sequenciamento completo desta estrutura para a espécie humana foram grandes conquistas. Porém, o desafio para o século 21 é trazer esta informação para uma abordagem funcional no organismo. $\mathrm{O}$ autor apresenta como a genética molecular e seus dogmas se alteraram, assim como os conceitos em biologia celular. Defende que, apesar dos grandes avanços que o sequenciamento completo do genoma humano possa trazer, este é apenas um estudo inicial, pois, para se entenderem os mecanismos químicos e fisiológicos da vida, muitos estudos ainda têm de ser feitos, sobretudo no campo das proteínas e do metabolismo. Assim, defende a importância do crescimento da proteômica, uma área que, em muito, pode contribuir para ajudar nesta busca "dos mistérios que a vida nos apresenta". O texto de Belizário (2000) ainda está impregnado de expressões que deturpam o sentido do PGH. Utilizando-se de expressões que apresentam o genoma como "arquivo oculto da vida" e "a força misteriosa e divina da vida", temos simplificações semânticas similares às criticadas expressões "livro da vida" ou "receita da vida", utilizadas por alguns autores com o intuito de apresentar, de forma simples, a importância e função do genoma ao grande público.

Em agosto, Mayana Zatz (2000) publicou o artigo intitulado "A importância dos estudos sobre o cromossomo 21" (v. 28, n. 163), divulgando a conclusão do sequenciamento desse cromossomo. Por meio deste artigo, conclui-se, equivocadamente, que, conhecendo-se um gene relacionado a uma doença, pode-se chegar a um tratamento imediato.

Em novembro de 2000 (v. 28, n. 166), o genoma foi matéria de capa da CH, em duas publicações diferentes na mesma edição, com grande número de páginas. Os artigos, organizados por Vera Costa (2000a, 2000b), são bastante diferentes entre si, sendo o primeiro mais uma contextualização do PGH, possivelmente para preparar o leitor para uma interpretação crítica do segundo, uma discussão ética conduzida pela jornalista científica e convidados.

Em "Genoma decifrado, trabalho dobrado" (COSTA, 2000a), ela relata um panorama do PGH após o anúncio em meio a seu ápice de popularidade: a divulgação do primeiro rascunho do genoma. Descreve, em números, os gastos do projeto até então, assim como a situação, o quadro existente de um sequenciamento incompleto, com algumas falhas e muito ainda a fazer. Neste artigo, vislumbra-se o que poderia, no futuro, ser chamado de Projeto Proteoma: o estudo da interação das proteínas codificadas por esses genes. A autora reproduz algumas 
das expectativas que rodeavam o projeto naquele momento, como o diagnóstico precoce para defeitos genéticos, assim como questões éticas, com comentários de Mayana Zatz. Fica clara a preocupação, presente há certo tempo, do desenvolvimento do "aperfeiçoamento genético", assim como a preocupação com a privacidade. Ela mantém uma retórica relativamente otimista, marcada pela ingenuidade, presente na consideração dos resultados da genômica como resposta às questões sobre o que é o ser humano.

O segundo artigo, "As promessas e os riscos", é reflexivo, onde, mais uma vez, a CH convida personalidades para responder questões sobre a temática do PGH. Entretanto, diferentemente do artigo "Como enfrentar os problemas éticos do Projeto Genoma Humano?" (1994), esse traz diferentes profissionais a manifestar sua opinião, como pesquisadores, religiosos e advogados, no objetivo de promover uma discussão mais abrangente sobre os impactos sociais, éticos e filosóficos deste empreendimento, por meio de distintas perspectivas. Por intermédio das questões "O que se pode esperar do sequenciamento do genoma humano?" e "Quais os principais problemas éticos e filosóficos que o sequenciamento traz?”, os convidados de Costa (2000b) expressam preocupações com as patentes de genes, a má interpretação desta ciência e até a sua influência no mercado de trabalho, onde o perfil genético poderia se mostrar, no futuro, mais um requisito a ser anexado no currículo de profissionais.

Um fato notório é que todos os profissionais consultados apresentam uma visão abrangente do PGH, até mesmo os teólogos, representados por um judeu e um cristão. Esses compartilham com biólogos, médicos e advogados, à sua maneira, o reconhecimento de potencialidades positivas e a preocupação com a propagação da discriminação genética e mau uso desse saber.

A publicação do rascunho do genoma, pelas revistas Nature e Science, em fevereiro de 2001, ocorreu no momento em que o mundo caminhava em um clima futurista no início do século XXI. Neste ano, a primeira publicação relacionada ao PGH foi uma entrevista com o físico e químico Walter Gilbert (2001), um dos pioneiros da tecnologia de sequenciamento do DNA, intitulada "Rumo ao Proteoma" (v. 29, n. 173). O artigo pode ser visto como uma reflexão sobre a perspectiva posterior aos resultados do rascunho do genoma. Ele afirma que "a revelação de que talvez tenhamos um número pequeno de genes mostra que devemos prestar mais atenção em aspectos como a interação das proteínas" (GILBERT, 2001, p. 10). É notório, no discurso de Gilbert (2001), o apoio à política de patenteamento de sequências gênicas. Para este, “o papel do patenteamento de genes e drogas é encorajar invenções” (GILBERT, 2001, p. 11). Essa opinião polêmica apresenta um equívoco entre o conceito de invenção e descoberta, já que os genes não são invenções humanas. Isto suscita questões éticas, como quem tem direitos sobre o que é natural, e se o patrimônio genético pode ser de tutela privada. No entanto, a opinião de Gilbert (2001) não surpreende, já que é um dos fundadores da Myriad Genetics, empresa de biotecnologia que ganhou fama ao patentear o teste genético de rastreamento de mutações nos genes BRCA1 e BRACA2, envolvidos no câncer de mama e ovário hereditários.

O artigo de abril de 2003, "Os desafios do proteoma" (v. 32, n. 192), de Adriano Pimenta, traz uma das melhores apresentações do proteoma, além de mostrar outros novos "omas", nascidos da base informacional construída pelo Projeto Genoma. É o primeiro artigo que declara a era "pós-genômica", que expressa a necessidade de desenvolver novos campos de pesquisa na Biologia Molecular para que possamos compreender os fenômenos moleculares que regem a "vida celular". Pimenta (2003) lança questões mais consistentes acerca da comple- 
xidade humana, pela perspectiva molecular, à luz de resultados importantes do sequenciamento, já publicados de 2001 a 2003, como a previsão de menos de 40 mil genes no genoma humano, e não os esperados 100 mil, apenas o dobro da quantidade de genes de vermes e moscas.

A descoberta de uma diversidade muito maior de proteínas do que de genes causou grande alvoroço, enfatizando a necessidade de se desenvolverem estudos para explicar esse fato, por meio dos mapas de interações metabólicas e proteicas das células. Nota-se um crescimento exponencial da importância da proteômica na virada do milênio, assim como a necessidade de novas áreas de estudo, como o transcriptoma e metaboloma, em meio às questões que surgiram com o avanço da tecnologia e dos conhecimentos na Biologia Molecular.

\section{A era pós-genômica}

Após 2003, o PGH já não mais rendia destaque nas publicações da $\mathrm{CH}$. O mapeamento de genomas tinha se tornado trivial e a tecnologia genômica abriu possibilidade ao desenvolvimento de projetos genoma de vários organismos, alguns apresentados pela própria CH, como o "Decifrado o genoma de três parasitos" (v. 37, n. 219), de Ana Paula Lima (2005). A consolidação do conhecimento genômico como uma ciência de base mostrava-se presente, também, em artigos como "Pequenos RNAs, um mundo novo e revolucionário" (v. 35, n. 206), de Maité Silva (2004).

Em 2004, duas entrevistas com enfoque na discussão de questões éticas e sociais e a relação ciência-sociedade foram publicadas. Ambas discutiram a não-neutralidade em ciência, apresentando uma perspectiva econômica acerca da pesquisa científica, onde interesses econômicos e de mercado, assim como as regras da política mundial, refletem um direcionamento de enfoques no desenvolvimento de estudos em ciência. Em março, uma entrevista intitulada "As modas da ciência" (v. 34, n. 202), com André Goffeau (2004), importante cientista no campo da biotecnologia, teve por foco a conduta de cientistas para defender projetos de pesquisa. Ele discute questões éticas relacionadas à manipulação de informações e à escolha do tema da pesquisa, em um contexto onde o desinteresse de investimentos em pesquisa de base e a priorização da pesquisa aplicada, assuntos que estão na "moda" na ciência, como foi o genoma, trazem financiamento a seu desenvolvimento. Em relação ao PGH, ele destaca que os frutos do PGH ainda demorarão muitos anos para amadurecer.

De forma similar, John Sulston (2004), químico britânico laureado com o Nobel de Medicina pelo seu trabalho com o C. elegans, e colaborador do PGH, também responde a uma entrevista, no artigo de setembro desse ano, "Ética e Genética" (v. 35, n. 208). Em suas respostas, apresenta um "mercado científico", onde as principais investigações e focos de financiamento se dão em pesquisa aplicada, que tenham algum retorno financeiro. $\mathrm{O}$ autor critica esse jogo de interesses no campo da ciência, que motiva a privatização de genes, e renega o combate de problemas de países pobres, não contemplados com benefícios de investigações científicas para essa finalidade.

Em outubro desse ano, a $\mathrm{CH}$ apresenta uma tecnologia essencial para a genômica, a Bioinformática. Em um artigo de fácil compreensão, "Sobre bioinformática, genoma e ciência” (v. 35, n. 209), Francisco Prosdocimi e Fabrício Santos (2004) discutem tanto tecnologia genômica, quanto história e crítica de ciência. Em um contexto onde a informação genética humana é revelada em um sem número de genes sequenciados e armazenados em bancos de 
dados, como o GenBank norte-americano, a bioinformática se desenvolveu para auxiliar na análise desta gama de informações. O artigo de Prosdocimi e Santos (2004) converge tecnologia e epistemologia, no contexto da Biologia Molecular onde se destaca a importância da tecnologia acessória às áreas científicas.

A matéria intitulada “O ponto X do sexo" (v. 36, n. 215), publicada em 2005, caracteriza o último artigo a noticiar um fato relacionado ao PGH, através da CH. Em um artigo pequeno, Souza (2005) apresenta as informações genéticas relacionadas ao cromossomo X. Sua discussão tem por foco a caracterização deste cromossomo, quanto às patologias a ele associado, assim como hipóteses para a origem autossômica desse, quando seu papel na determinação do sexo é comparado ao de outros grupos, como o das aves. Sendo o cromossomo X considerado muito importante e de grande destaque quando se discute cromossomos em genética, possivelmente esse foi o fato que trouxe, novamente, o tema sequenciamento em um artigo próprio.

O último artigo selecionado nesta evolução histórica, "DNA Não-Codificador: o lixo que vale ouro" (v. 38, n. 228) de Paulo Amaral e Helder Nakaya, publicado em 2006, caracteriza os principais resultados do PGH como uma informação de base, popularizada como conhecimento consolidado em Biologia Molecular. Observa-se que o genoma é apresentado de forma comum, como referencial teórico para se entender o escopo da discussão que trazem sobre o "DNA-lixo". Neste artigo, resultados da genômica têm destaque no quadro comparativo de genomas de organismos, o qual mostra que o número de genes da espécie humana não é muito diferente de peixes, vermes ou protozoários. O principal foco do artigo é a apresentação da relevância do DNA não-codificador, tradicionalmente negligenciado, que ganhou enorme destaque após os avanços em Biologia Molecular decorrentes dos resultados do PGH.

A era pós-genômica consistiu no desenvolvimento da proteômica, transcriptômica e metabolômica, assim como no estudo de regiões não codificantes do DNA, rico em micro-RNAs e sequências reguladoras da expressão gênica.

Em meio a uma miscelânea de fatos científicos noticiados pela $\mathrm{CH}$, o $\mathrm{PGH}$ já não configurava mais um assunto a merecer grande destaque, tendência a se notar nos artigos após 2003. Assim como a descrição da estrutura em dupla-hélice da molécula de DNA tornou-se inerente a toda uma Biologia Molecular que estava nascendo, agora o conhecimento genômico adquire essa característica, como um marco inicial a uma Biologia Molecular do século XXI.

\section{Considerações finais}

De acordo com Scheid, Ferrari e Delizoicov (2005), a inclusão da História da Ciência, entendida de forma mais ampla, como a história da construção do conhecimento, pode ser uma facilitadora da educação científica, quando o pressuposto é o aspecto dinâmico do saber científico. Ao ser utilizada no ensino de Genética, deverá levar o aluno a perceber que a ciência se constitui numa construção sócio-histórico-cultural. O Projeto Genoma Humano faz parte de um momento histórico na evolução do conhecimento científico em Genética e Biologia Molecular. Tivemos como objetivo mostrar como este conhecimento foi construído por meio da análise de artigos e reportagens publicados durante o período de 1984 a 2010 na revista de divulgação científica Ciência Hoje. 
No decorrer de um pouco mais de duas décadas, o Projeto Genoma Humano se mostrou um dos ícones de avanço científico e tecnológico. Claramente abordado neste período, o PGH foi notícia recorrente, sendo eventualmente citado em artigos com outras abordagens, sobretudo após a consolidação das tecnologias de sequenciamento, onde o genoma de diversas espécies ganhou bancos de dados, em um crescente esforço de descrição biológica. De forma similar aos taxonomistas e sistematas, que caracterizam uma espécie pela sua morfologia, agora, o genoma tem seus caracteres identificados.

A abordagem do PGH por meio da $\mathrm{CH}$ acompanhou as expectativas fantásticas que o mundo cultivava acerca do projeto. Notou-se grande euforia no início do projeto, onde autores apresentavam fatos e números, imersos em uma névoa de excitação. Essa exaltação difundia uma ideia do sequenciamento como o marco entre a biologia de estudos restritos e pontuais do século XX e a nova biologia do século XXI, holista, capaz de analisar o indivíduo por inteiro por meio de seu mapa gênico. Perspectivas exacerbadas traziam, no mapa completo do genoma, a resposta para todas as perguntas celulares. Mas, concluiu-se que ainda serão necessários muitos anos, décadas, séculos, até que o que se esperou responder com o genoma torne-se informação palpável para ajudar a responder questões complexas de uma perspectiva holista e completa do funcionamento do nosso organismo.

Por outro lado, novos campos de pesquisa surgiram, como a proteômica e a transcriptômica. Algumas doenças genéticas também têm sido tratadas por meio de terapia gênica.

No entanto, a questão de James Watson, “o que é ser humano?” (LEITE, 2006), talvez não seja respondida nem pelos: proteoma, transcriptoma, metaboloma, interatoma, reguloma, epigenoma, ou qualquer outro descendente do genoma. A era pós-genômica caracterizou-se pela conscientização de um cenário de maior complexidade do que se esperava quanto aos mecanismos celulares de informação gênica e regulação de sua expressão.

Finalmente, é interessante ressaltar a incontestável relação entre as corridas genômica e a da chegada à Lua, ambas realizadas entre os países "tecnologicamente competentes" para participar. A primazia genômica dos Estados Unidos foi defendida com o mesmo fervor que colocou os astronautas norte-americanos na Lua, antes dos soviéticos. Nos Estados Unidos, ambas as corridas estavam imbuídas de uma superexpectativa de dias melhores, assim como melhores condições de vida. No entanto, estamos ainda tentando digerir a informação gerada por ambos os projetos. Esta reflexão nos aponta um caminho mais humilde, onde a única certeza é a de que estamos apenas no começo.

\section{Referências}

ADAMS, D. A. et al. The genome sequence of Drosophila melanogaster. Science, Washington, v. 287, n. 5461, p. 2185-2195, 24 Mar. 2000.

\section{ALVETTI, M. A. S. Ensino de física moderna e contemporânea e a revista Ciência}

Hoje. 1999. 169 f. Dissertação (Mestrado em Educação) - Universidade Federal de Santa Catarina, Florianópolis, 1999. 
AMARAL, P. P. R.; NAKAYA, H. I. DNA não-codificador: o lixo que vale ouro. Ciência Hoje, Rio de Janeiro, v. 38, n. 228, p. 36-42, jul. 2006.

BELIZÁRIO, J. E. Proteoma: o desafio tecnológico do século 21. Ciência Hoje, São Paulo, v. 27 , n. 162 , p. $78-81$, jul. 2000.

CAPOZOLI, U. Genoma humano: analfabetismo científico na mídia. Observatório da Imprensa, São Paulo, n. 110, 28 fev. 2001. Disponível em: < http:/ /www. observatoriodaimprensa.com.br/ofjor/ofc280220011.htm>. Acesso em: 25 mar. 2011.

COMO enfrentar os problemas éticos do Projeto Genoma Humano? Ciência Hoje, São Paulo, v. 17, n. 99, p. 31-35, abr. 1994.

COSTA, V. R. As promessas e os riscos. Ciência Hoje, São Paulo, v. 28, n. 166, p. 28-35, nov. 2000a.

. Genoma decifrado, trabalho dobrado. Ciência Hoje, São Paulo, v. 28, n. 166, p. 22-27, nov. 2000 b.

GALLER, R. Decifrando os genes humanos. Ciência Hoje, São Paulo, v. 5, n. 29, p. 16-17, mar. 1987.

GARCIA, E. S. O passo seguinte do genoma. Ciência Hoje, São Paulo, v. 24, n. 144, p. 50-51, nov. 1998.

GILBERT, W. Rumo ao proteoma. Ciência Hoje, São Paulo, v. 29, n. 173, p. 8-11, jul. 2001.

GOFFEAU, A. As modas da ciência. Ciência Hoje, Rio de Janeiro, v. 34, n. 202, p. 8-10, mar. 2004.

GUIMARÃES FILHO, A. P. A pré-história hoje. Ciência Hoje, São Paulo, v. 14, n. 82, p. 40 , jul. 1992.

LEITE, M. As promessas do genoma. São Paulo: Ed. da Unesp, 2006.

LEITE, R. C. M. A produção coletiva do conhecimento científico: um exemplo no ensino de genética. 2004. 219 f. Tese (Doutorado em Educação) - Centro de Ciências da Educação, Universidade Federal de Santa Catarina, Florianópolis, 2004.

LIMA, A. P. C. A. Decifrado o genoma de três parasitas. Ciência Hoje, São Paulo, v. 37, n. 219, p. 12, set. 2005.

MASSARANI, L. Combate a doenças tropicais. Ciência Hoje, São Paulo, v. 101, n. 18, p. 88-90, jul. 1994.

MOREIRA, I. C. A inclusão social e a popularização da ciência e tecnologia no Brasil. Inclusão Social, Brasília, v. 1, n. 2, p. 11-16, abr-set. 2006.

PENA, S. D. Dez anos de genoma humano. Ciência Hoje, Rio de Janeiro, 11 jun. 2010. Disponível em: < http://cienciahoje.uol.com.br/colunas/deriva-genetica/dez-anos-degenoma-humano>. Acesso em: 12 nov. 2010. 
PIMENTA, A. M. C. Os desafios do proteoma. Ciência Hoje, Rio de Janeiro, v. 32, n. 192, p. 16-22, abr. 2003.

PINHEIRO, N. A. M.; SILVEIRA, R. M. C. F.; BAZZO, W. A. Ciência, tecnologia e sociedade: a relevância do enfoque CTS para o contexto do ensino médio. Ciência $\&$ Educação, Bauru, v. 13, n. 1, p. 71-84, 2007.

PORCIONATTO, M. A. Projeto Genoma Humano: uma leitura atenta do livro da vida? Circumscribere: international journal for the history of science, São Paulo, v. 2, p. 51-63, 2007. Disponível em: < http://revistas.pucsp.br/index.php/circumhc/article/ viewFile/573/1031>. Acesso em: 18 jun. 2014.

O PRIMEIRO mapa do genoma. Ciência Hoje, São Paulo, v. 17, n. 99, p. 50-51, abr. 1994.

PROSDOCIMI, F.; SANTOS, F. S. Sobre bioinformática, genoma e ciência. Ciência Hoje, Rio de Janeiro, v. 35, n. 209, p. 54-57, out. 2004.

PRONIN, T. Dez anos depois, repercussão do genoma no tratamento de doenças é limitada. UOL Notícias, São Paulo, 26 jun. 2010. Disponível em: < http://noticias.uol.com.br/ ultnot/cienciaesaude/ultimas-noticias/2010/06/26/primeiro-esboco-do-genoma-humanocompleta-dez-anos-neste-sabado-26.jhtm>. Acesso em: 11 nov. 2010.

RUMJANEK, F. O 22 já foi, só faltam 22. Ciência Hoje, São Paulo, v. 27, n. 158, p. 11-12, mar. 2000.

SCHEID, N. M. J.; FERRARI, N.; DELIZOICOV, D. A construção coletiva do conhecimento científico sobre a estrutura do DNA. Ciência \& Educação, Bauru, v. 11, n. 2, p. 223-233, 2005.

SILVA, M. V. F. Pequenos RNAs: um mundo novo e revolucionário. Ciência Hoje, São Paulo, v. 35, n. 206, p. 30, jul. 2004.

SOUZA, S. J. O ponto X do sexo. Ciência Hoje, Rio de Janeiro, v. 36, n. 215, p. 11-12, maio 2005.

SULSTON, J. Ética e genética. Ciência Hoje, Rio de Janeiro, v. 35, n. 208, p. 8-11, set. 2004. VENTER, J. C. et al. The sequence of the human genome. Science, Washington, v. 291, n. 5507, p. 1304-1351, 16 fev. 2001.

VIEIRA, C. L.; MASSARANI, L.; MUNIZ, M. A megaciência dos genes. Ciência Hoje, São Paulo, v. 15, n. 88, p. 52-57, mar. 1993.

ZATZ, M. A importância dos estudos sobre o cromossomo 21. Ciência Hoje, São Paulo, v. 28 , n. 163 , p. 13-14, ago. 2000. 